\title{
Technical Cashew Nutshell Liquid in Diets of Growing Meat-Type Quails
}

\section{-Author(s)}

Sanches LM' (iD https://orcid.org/0000-0003-2610-7810 Eyng C" (D) https://orcid.org/0000-0001-8839-3758 Garcia RG' (iD https://orcid.org/0000-0002-4978-9386 Alves GPI (iD) https://orcid.org/0000-0002-7190-6200 Sangalli GG" (D) https://orcid.org/0000-0003-0329-1627 Nunes RV (iD https://orcid.org/0000-0002-9376-2826

Universidade Federal da Grande Dourados, MS, Brazil.

" Universidade Estadual do Oeste do Paraná, PR, Brazil.

\section{Mail Address}

Corresponding author e-mail address Cinthia Eyng

Universidade Estadual do Oeste do Paraná Centro de Ciências Agrárias, Rua

Pernambuco, 1777 - Centro - Marechal Cândido Rondon, PR, 85960-000, Brazil.

Phone: +55 45998000893

Email: cinthiaeyng@hotmail.com

\section{- Keywords}

Carcass traits, cardanol, meat-type quails, natural additive.

\section{ABSTRACT}

The aim of this study was to evaluate the inclusion of technical cashew nutshell liquid (TCNSL) in European quails (Coturnix coturnix coturnix) diets from 1 to 35 days of age on the performance, carcass traits, and development of the digestive organs. 575 quails were distributed in a completely randomized design with five treatments $(0 \%, 0.25 \%$, $0.50 \%, 0.75 \%$, and $1.00 \%$ TCNSL), five replicates, and 23 birds per experimental unit. Live performance was evaluated by weight gain, average feed intake, and feed to conversion ratio. The relative weight of the digestive organs (proventriculus, gizzard, pancreas, liver, small intestine, and large intestine), length of the small and large intestine, and carcass and parts yield (breast, wing, and leg) were determined at the end of the experimental period ( 35 days). The supplementation of quail diets with TCNSL did not influence live performance or carcass and parts yields. The relative weights of the proventriculus, gizzard, pancreas, small intestine, and large intestine, and the length of the small intestine and large intestine were not affected by the dietary inclusion of TCNSL. However, TCNSL supplementation had a quadratic effect $(p<0.05)$ on liver relative weight, with the lowest relative weight predicted at $0.33 \%$ TCNSL. Quails fed 1\% TCNSL showed higher liver relative weight compared with those fed the TCNSL-free diets. The dietary inclusion of up to $1 \%$ TCNSL did not influence the performance, carcass traits, or development of the digestive organs of European quails.

\section{INTRODUCTION}

The concern of consumers about the possibility of antibiotic residues in animal food products as well as the ban on antibiotics as a performance enhancer in many European countries have recently boosted research on natural additives. Among the several additives studied, functional oils have aroused interest because of their secondary plant metabolites, compounds that act to protect the plant against pathogens. When added to feed, these substances can improve both health and animal performance, in addition to their nutritional value (Murakami et al., 2014).

Cashew nutshell liquid (CNSL), obtained from cashew fruit peel, contains cardanol, anacardic, cardol, and 2-methylcardol acids in its composition (Trevisan et al., 2006), which confer many biological activities, such as antimicrobial (López et al., 2012) and antioxidant properties (Abreu et al., 2017). In general, these substances help to balance the intestinal microbiota by inhibiting the growth of pathogenic bacteria by inducing cellular apoptosis (Muzaffar \& Chattoo, 2017) and favoring the growth of beneficial bacteria that aid digestive and absorptive processes. Moreover, these compounds can act as free radical scavengers, acting not only in the initial stage of the oxidative 
process but also in their propagation, with antioxidant activity at the cellular level in the animal organism (Toyomizu et al., 2000) or in animal food products, extending their shelf life (Abreu et al., 2015).

In fact, some studies have demonstrated positive performance results of broiler chickens when coproducts from the processing of cashew nuts or even cashew nut meal were incorporated in diets (Ojewola et al., 2004; Tanod et al., 2015), and reduced Escherichia coli counts in the intestinal contents (López et al., 2012). Bess et al. (2012), studying a commercial mixture of functional oils containing CNSL, observed better performance parameters in broilers, even when the birds were fed a diet with a reduction of $100 \mathrm{kcal}$ metabolizable energy $/ \mathrm{kg}$, demonstrating that the dietary inclusion of the product improved nutrient digestibility. In addition, some authors (Toyomizu et al., 2003; Murakami et al., 2014) evaluated CNSL as a natural anticoccidial and found a reduction of the severity of cecal lesions of chickens infected with coccidia, suggesting they act as ionophores. However, despite these positive effects, Farias et al. (2017) did not observe any changes in the performance traits and gastrointestinal development of laying quails fed fresh or 180-d stored cashew nut meal.

This heterogeneity of results may be related to the concentration of these compounds, which vary with the extraction method used. When obtaining CNSL by using solvents, there is a high concentration of anacardic acid, whereas heat processing favors the decarboxylation of this acid, resulting in a high content of cardanol (Mazzetto et al., 2009), and it is named technical CNSL (TCNSL). In this context, anacardic acid has higher antioxidant and enzyme-inhibiting capacities relative to the other compounds in CNLS (Trevisan et al., 2006) due the presence of three double bonds in the alkyl side-chain (Stasiuk \& Kozubek, 2010). Nevertheless, in-vitro assays demonstrated that TCNSL may have a protective effect against oxidative stress (Andrade et al., 2011), but there are still few studies on the effects of feeding TCNSL and its effects on the animals' organism.

Considering the above, the aim of this study was to evaluate the effects of feeding different TCNSL levels to European quails on their performance, carcass yield, and relative weight of the digestive organs.

\section{MATERIAL AND METHODS}

The experiment was performed at the Poultry Research Center of the Federal University of Grande
Dourados, Dourados, Mato Grosso do Sul, Brazil. The experimental procedures complied with the ethical principles for animal experimentation established by the Brazilian Association for Laboratory Animal Science (SBCAL) and the National Council for the Control of Animal Experimentation (CONCEA).

The poultry house was divided in floor pens, measuring $2.12 \mathrm{~m}^{2}$ each, covered with new woodshavings litter, and equipped with tube feeders and bell drinkers. House temperature was controlled by a negative pressure system and infrared heating lamps. House temperature and relative humidity were daily measured using digital thermo-hygrometers (Instrutemp, ITHT 2250, São Paulo, Brazil) placed at birds' height. Average maximum and minimum temperatures were 31.0 and $26.2^{\circ} \mathrm{C}$, respectively. Average maximum and minimum relative humidity were 75.5 and $57.6 \%$, respectively.

In all, 575 one-d-old male and female European quails (Coturnix coturnix coturnix) were distributed according to a completely randomized design into five dietary treatments $(0 \%, 0.25 \%, 0.50 \%, 0.75 \%$, or $1.00 \%$ of TCNSL) with five replicates of 23 birds each. Birds were reared until 35 days of age.

The TCNSL was purchased from the company Usibras (Aquiraz, Ceará, Brazil) and stored under refrigeration until the preparation of the experimental diets. According to a report of the manufacturer, the concentrations of anacardic, cardanol, cardol, and 2-methylcardol acids were $10.03 \mathrm{mg} / \mathrm{g}, 540.77 \mathrm{mg} / \mathrm{g}$, $102.34 \mathrm{mg} / \mathrm{g}$, and $19.17 \mathrm{mg} / \mathrm{g}$ of product, respectively.

The isoenergetic and isoprotein experimental diets were formulated to meet the nutritional requirements proposed by Rostagno et al. (2011) for the phases of 1 to 14 and 15 to 35 days of age (Table 1). Throughout the experimental period, water and feed were supplied ad libitum. A continuous lighting program was adopted (24 h of natural + artificial light).

Performance parameters (weight gain, average feed intake, and feed conversion ratio) were determined per experimental unit for the periods of 1 to 14 days (phase 1) and from 15 to 35 days of age (phase 2). Weight gain (g) was calculated by subtracting initial body weight (BW) from final BW, and feed intake (g) was determined as the difference between feed offer and feed residues in the feeders at the end of each phase. Feed conversion ratio was calculated by dividing average feed intake by average weight gain. Average feed intake and feed conversion were daily adjusted for mortality. 
Table 1 - Ingredients and calculated nutritional composition of the experimental diets.

\begin{tabular}{|c|c|c|}
\hline \multirow[b]{2}{*}{ Ingredients (\%) } & \multicolumn{2}{|c|}{ Period (days) } \\
\hline & 1 to 14 & 15 to 35 \\
\hline Corn & 47.186 & 54.477 \\
\hline Soybean meal, $45 \%$ & 46.220 & 38.700 \\
\hline Soybean oil & 2.700 & 3.620 \\
\hline Limestone & 1.040 & 0.930 \\
\hline Dicalcium phosphate & 1.350 & 0.980 \\
\hline $\mathrm{NaCl}$ & 0.381 & 0.331 \\
\hline Inert material ${ }^{*}$ & 0.100 & 0.100 \\
\hline DL- Met, $98 \%$ & 0.385 & 0.352 \\
\hline L-Lys sulfate, $50,7 \%$ & 0.182 & 0.260 \\
\hline L-Thr, 98\% & 0.206 & 0.000 \\
\hline Supplement minerals and vitamins ${ }^{1}$ & 0.250 & 0.250 \\
\hline Total & 100 & 100 \\
\hline \multicolumn{3}{|l|}{ Calculated nutritional composition } \\
\hline Crude protein (\%) & 25 & 22 \\
\hline Metabolizable energy (kcal/kg) & 2900 & 3050 \\
\hline Calcium (\%) & 0.850 & 0.700 \\
\hline Available phosphorus (\%) & 0.380 & 0.300 \\
\hline Digestible Met + Cys (\%) & 1.040 & 0.940 \\
\hline Digestible Lys (\%) & 1.370 & 1.230 \\
\hline Digestible Thr (\%) & 1.040 & 0.760 \\
\hline Digestible Trp (\%) & 0.290 & 0.250 \\
\hline
\end{tabular}

${ }^{1}$ Mineral and vitamin supplement (content per $\mathrm{kg}$ of product): folic acid $80 \mathrm{mg}$; pantothenic acid $2200 \mathrm{mg}$; copper $3600 \mathrm{mg}$; choline $40 \mathrm{mg}$; iron $18 \mathrm{mg}$; butylated hydroxy-toluene $150 \mathrm{mg}$; iodine $300 \mathrm{mg}$; manganese $30 \mathrm{~g}$; niacin $6000 \mathrm{mg}$; selenium 120 mg; vitamin A $2800000 \mathrm{lU}$; vitamin $\mathrm{B}_{1} 340 \mathrm{mg}$; vitamin $\mathrm{B}_{12} 2800 \mathrm{cg}$; vitamin $\mathrm{B}_{2} 1000$ $\mathrm{mg}$; vitamin $\mathrm{B}_{6} 560 \mathrm{mg}$; vitamin $\mathrm{D}_{3} 600000 \mathrm{IU}$; vitamin E $2000 \mathrm{IU}$; vitamin $\mathrm{K}_{3} 480 \mathrm{mg}$; zinc 28g.

* The technical cashew nutshell liquid was added to diet in replacement of inert material (kaolin).

On d 35, two males per replicate (average BW \pm $5 \%)$ were fasted for six hours and then slaughtered by decapitation between the occipital and atlas bones. The relative weight (as a $\%$ of BW) of the gastrointestinal organs (proventriculus, gizzard, small intestine, large intestine, pancreas, and liver) and the length $(\mathrm{cm})$ of the small and large intestine (colon, rectum, and cecum) were determined. Carcass yield was calculated as the ratio of the hot eviscerated carcass (without head, feet, neck, and abdominal fat) to BW at slaughter. Parts yield (breast, wing, and leg) was calculated as their weight relative to eviscerated carcass weight.

The results were submitted to analysis of variance, and Dunnett's test was applied to compare the differences between the control treatment $(0 \%$ TCNSL) and each TCNSL inclusion level. Data were also submitted to regression analysis by polynomial decomposition of the degrees of freedom. All the statistical analyses were performed using the SAEG System for Statistical and Genetic Analysis (2007), and a probability of $<0.05$ was considered significant.

\section{RESULTS AND DISCUSSION}

Although CNSL is typically used as a raw material for manufacturing waterproofing agents, paints, varnishes, plastics, and other products (Akinhanmi et al., 2008), its phenolic composition (cardanol, anacardic, cardol, and 2-methylcardol acids) has attracted the interest of nutritionists because it is correlated to several biological activities, such as antimicrobial (López et al., 2012) and antioxidant properties (Abreu et al., 2017).

According to the literature, the concentration of compounds in the final product depends on the processing conditions. Extraction by maceration of the cashew nutshell with solvents at room temperature produces a liquid with high anacardic acid level, whereas roasting at high temperatures favors the decarboxylation of anacardic acid, increasing the final content of cardanol, which is classified as technical CNSL (Paramashivappa et al., 2001; Kumar et al., 2002). According to a report from the manufacturer, the concentrations of anacardic, cardanol, cardol, and 2-methylcardol acids found in the CNSL used in the experiment were $10.03 \mathrm{mg} / \mathrm{g}, 540.77 \mathrm{mg} / \mathrm{g}, 102.34$ $\mathrm{mg} / \mathrm{g}$, and $19.17 \mathrm{mg} / \mathrm{g}$, respectively, characterizing it as TCNSL.

Among the compounds isolated from CNSL, anacardic acid is the most frequently lipid reported in the literature, since it is biologically more efficient than the other compounds identified (Himejima \& Kubo, 1991; Trevisan et al., 2006). Nevertheless, other CNSL components, such as cardanol, including one of its main compounds, cardanol monoene, are also capable of benefiting the animal's body due to their antioxidant, bactericidal, and anti-cancer activities (Andrade et al., 2011; Su et al., 2017).

Several modes of action of the bioactive compounds identified in CNSL have been described. The amphipathic character of the acids allows them to pass through the lipid bilayer of bacteria, inhibiting the activity of enzymes involved in the synthesis of energy and lipids (Murata et al., 1997; Parasa et al., 2011). Their effectiveness is greater against gram-positive than gram-negative bacteria due to the lower structural complexity of the membrane of the former (Himejima \& Kubo, 1991). Therefore, they are able to modulate the intestinal microbiota, causing the death of specific microorganism groups considered pathogenic to the animal. In addition, these compounds may inhibit the pro-oxidative enzymes involved in the production of free radicals and have a binding specificity to some metals, such as $\mathrm{Fe}^{2+}$ and $\mathrm{Cu}^{2+}$, reducing their availability 
for both bacteria and for the conversion of reactiveoxygen species (Hemshekhar et al., 2011; Parasa et al., 2011).

Despite the previously reported beneficial effects of biological substances, the dietary TCNSL supplementation did not influence ( $p>0.05$ ) quail performance or carcass and parts yields (Tables 2 and 3) at any of the evaluated levels.

The relative weight of the proventriculus, gizzard, pancreas, small intestine, and large intestine, and

Table 2 - Body weight gain, feed intake, and feed:gain of growing meat-type quails fed diets with different levels of technical cashew nutshell liquid (TCNSL).

\begin{tabular}{|c|c|c|c|c|c|c|}
\hline & \multicolumn{3}{|c|}{1 to 14 days of age } & \multicolumn{3}{|c|}{15 to 35 days of age } \\
\hline TCNSL level (\%) & Body weight (g) & Feed intake (g) & Feed:gain & Body weight (g) & Feed intake $(\mathrm{g})$ & Feed:gain \\
\hline 0.00 & 67.595 & 129.961 & 1.929 & 132.848 & 453.545 & 3.409 \\
\hline 0.25 & 69.811 & 134.736 & 1.927 & 135.530 & 430.026 & 3.172 \\
\hline 0.50 & 64.874 & 135.985 & 2.091 & 138.016 & 421.250 & 3.055 \\
\hline 0.75 & 67.863 & 136.538 & 2.019 & 134.184 & 426.396 & 3.183 \\
\hline 1.00 & 69.327 & 131.498 & 1.893 & 132.470 & 430.967 & 3.256 \\
\hline CV (\%) & 8.00 & 11.63 & 8.72 & 4.95 & 7.19 & 5.90 \\
\hline$P$ Dunnett's test & 0.720 & 0.958 & 0.453 & 0.701 & 0.616 & 0.126 \\
\hline \multicolumn{7}{|c|}{$P$ Regression analysis } \\
\hline Linear & 0.803 & 0.836 & 1.000 & 0.770 & 0.343 & 0.394 \\
\hline Quadratic & 0.529 & 0.465 & 0.133 & 0.207 & 0.217 & 0.180 \\
\hline
\end{tabular}

$\mathrm{CV}=$ coefficient of variation; Not significant by Dunnett's test $(p>0.05)$

Table 3 - Carcass and parts yields (\%) of growing meat-type quails at 35 days of age fed diets with different levels of technical cashew nutshell liquid (TCNSL).

\begin{tabular}{|c|c|c|c|c|}
\hline TCNSL level (\%) & $\begin{array}{c}\text { Carcass yield (CY) } \\
(\% \mathrm{BW})\end{array}$ & $\begin{array}{l}\text { Breast yield } \\
(\% \text { CY })\end{array}$ & $\begin{array}{l}\text { Leg yield } \\
\text { (\% CY) }\end{array}$ & $\begin{array}{c}\text { Wing yield } \\
(\% \text { CY })\end{array}$ \\
\hline 0.00 & 70.62 & 40.93 & 24.38 & 10.87 \\
\hline 0.25 & 72.07 & 39.69 & 25.58 & 11.28 \\
\hline 0.50 & 72.35 & 41.58 & 23.71 & 10.74 \\
\hline 0.75 & 71.43 & 41.05 & 23.94 & 11.04 \\
\hline 1.00 & 70.45 & 40.56 & 24.69 & 9.84 \\
\hline $\mathrm{CV}(\%)$ & 2.68 & 5.03 & 6.33 & 15.26 \\
\hline$P$ Dunnett's test & 0.443 & 0.675 & 0.378 & 0.696 \\
\hline \multicolumn{5}{|c|}{$P$ Regression analysis } \\
\hline Linear & 0.721 & 0.832 & 0.650 & 0.334 \\
\hline Quadratic & 0.073 & 0.788 & 0.649 & 0.400 \\
\hline
\end{tabular}

$C V=$ coefficient of variation; Not significant by Dunnett's test $(p>0.05)$.

the length of the small intestine and large intestine of 35 - $d$-old quails were not affected ( $p>0.05)$ by the dietary inclusion of TCNSL at any levels (Table 4). However, TCNSL supplementation had a quadratic effect $(p<0.05)$ on liver relative weight, with the lowest relative weight predicted at $0.33 \%$ TCNSL (Figure 1). When comparing each inclusion level against the control, it was observed that quails fed $1 \%$ TCNSL had higher liver relative weight compared with those fed TCNSL-free diets (Table 4).

The lack of influence of the dietary inclusion of TCNSL on quail performance and carcass yield parameters observed in the present study may be due to a several intrinsic and extrinsic factors, including experimental methods (Windisch et al., 2008). In the current experiment, the optimal rearing environmental conditions, reduced health challenge, and adequate management conditions may account for these results. In addition, the supply of highly-digestible diets may have reduced the availability of substrates for bacterial proliferation (Lee et al., 2003), and therefore, the expected benefits were not expressed. In fact, Murakami et al. (2014), evaluating the effect of the inclusion of functional oils (CNSL and castor oil) in the diets of broilers challenged with Eimeria spp., observed that those fed diets containing oils showed greater economic feasibility and reduced lesions caused by the protozoan, evidencing the benefits of substances derived from functional oils under challenging environments.

Furthermore, there is limited information on the interaction between the biological activity of natural 
Table 4 - Relative weight of gastrointestinal organs (\%), and length of the small and large intestine $(\mathrm{cm})$ of growing meattype quails fed diets with different levels of technical cashew nutshell liquid (TCNSL).

\begin{tabular}{|c|c|c|c|c|c|c|c|c|}
\hline \multirow[b]{2}{*}{ TCNSL level (\%) } & \multirow[b]{2}{*}{ Proventriculus } & \multicolumn{3}{|c|}{ Relative weight (\% BW) } & \multirow[b]{2}{*}{ Small intestine } & \multirow[b]{2}{*}{ Large intestine } & \multicolumn{2}{|c|}{ Length $(\mathrm{cm})$} \\
\hline & & Gizzard & Liver & Pancreas & & & Small intestine & Large intestine \\
\hline 0.00 & 0.387 & 1.876 & 1.899 & 0.218 & 1.922 & 0.603 & 50.300 & 17.950 \\
\hline 0.25 & 0.455 & 2.119 & 1.885 & 0.247 & 2.338 & 0.637 & 57.300 & 19.950 \\
\hline 0.50 & 0.430 & 2.046 & 1.895 & 0.234 & 2.329 & 0.563 & 55.350 & 19.700 \\
\hline 0.75 & 0.404 & 2.068 & 1.874 & 0.265 & 2.195 & 0.628 & 51.350 & 19.450 \\
\hline 1.00 & 0.412 & 1.985 & $2.350 *$ & 0.253 & 2.449 & 0.668 & 55.200 & 20.250 \\
\hline $\mathrm{CV}(\%)$ & 15.67 & 10.26 & 12.42 & 19.15 & 14.74 & 15.64 & 7.38 & 14.12 \\
\hline$P$ Dunnett's test & 0.544 & 0.422 & 0.024 & 0.572 & 0.155 & 0.530 & 0.057 & 0.715 \\
\hline \multicolumn{9}{|c|}{$P$ Regression analysis } \\
\hline Linear & 0.990 & 0.574 & 0.018 & 0.205 & 0.066 & 0.387 & 0.502 & 0.304 \\
\hline Quadratic & 0.285 & 0.122 & $0.032^{1}$ & 0.625 & 0.426 & 0.365 & 0.224 & 0.607 \\
\hline
\end{tabular}

$\mathrm{CV}=$ coefficient of variation; Significant by Dunnett's test $(p<0.05){ }^{1}{ }^{\mathrm{Y}}=1.93788228-0.72798168 \mathrm{x}+1.08486560 \mathrm{x}^{2}\left(\mathrm{R}^{2}=0.84\right)$ (Minimum point: $0.33 \%$ of TCNLS).

additive compounds and nutritional factors, including nutrient levels and diet type (Zeng et al., 2015). Jamroz et al. (2006) observed higher jejunal villi in chickens fed on maize diet supplemented with plant extract than in those fed diets based on wheat and barley.

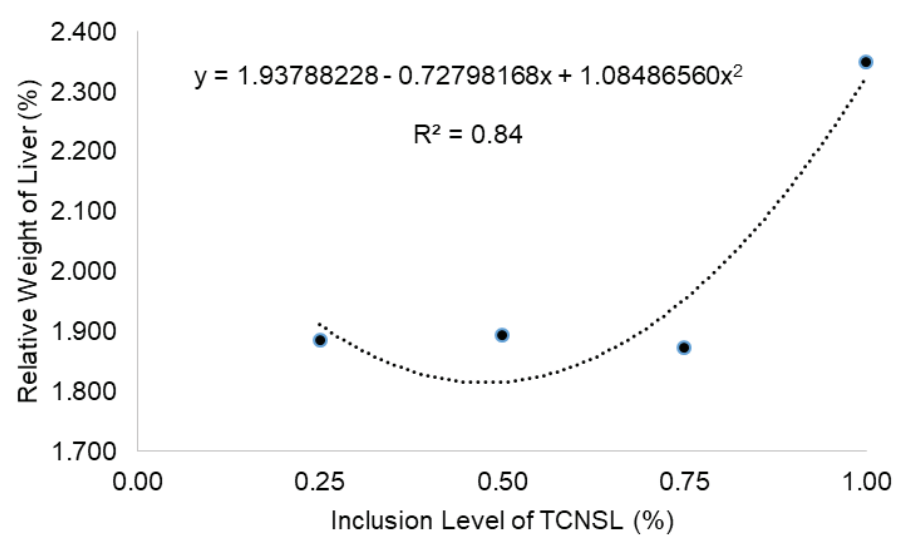

Figure 1 - Effect of different levels of technical cashew nutshell liquid (TCNSL) on liver relative weight (\%) of growing meat-type quails.

Technical cashew nutshell liquid in diets of growing meat-type quails; Lorena Mari Sanches, Cinthia Eyng, Rodrigo Garófallo Garcia, Gislaine Paganucci Alves, Gabriela Glaeser Sangalli, Ricardo Vianna Nunes

The analysis of the relative weight of the digestive organs can be used as an indirect indicator of their health and functionality. The liver is the organ responsible for the metabolism of substances harmful to the organism, and therefore, any possible interference in the hepatic metabolism may change its size (Simsek et al., 2007). In fact, anacardic acid and, to a lesser extent cardanol (Andrade et al., 2011) may modulate liver antioxidant activity by acting on the uncoupling oxidative phosphorylation in mitochondria and causing a small inhibition in respiration rate (Toyomizu et al., 2000; Hamad \& Mubofu, 2015). In this context, the observed effect on the liver relative weight may be related with beneficial changes in liver metabolism, including low lipid peroxidation and to the absence of hepatic dysfunction, since no toxic effects were observed with the use of isolated cardanol, the compound with the highest concentration in the TCNSL used (Leite et al., 2015). Braz et al. (2017) did not observe any changes in the concentration of non protein sulfhydryl groups in the liver of laying hens fed diets containing CNSL, indicating no toxic effects of its compounds. Contrary to the observations in this study, López et al. (2012) and Farias et al. (2017) did not observe any changes in liver relative weight when feeding TCNSL to broilers and cashew nut meal to quails, respectively.

\section{CONCLUSION}

The dietary inclusion of up to $1 \%$ TCNSL did not influence the performance, carcass traits, or development of the digestive organs of European quails.

\section{REFERENCES}

Abreu VKG, Pereira ALF, Freitas ER, Trevisan MTS, Costa JMC. Addition of anacardic acid as antioxidants in broiler chicken mortadella. Food Science and Technology 2015;35(3):539-545.

Abreu VKG, Pereira ALF, Freitas ER, Trevisan MTS, Costa JMC, Braz NM. Cashew nutshell liquid supplementation and the effect on lipid oxidation and color in fresh and spray-dried eggs. Journal of Food Processing and Preservation 2017;41(4):1-9.

Akinhanmi TF, Atasie VN, Akintokun PO. Chemical composition and physicochemical properties of cashew nut (Anacardiumoccidentale) oil and cashew nutshell liquid. Journal of Agricultural, Food, and Environmental Sciences 2008;2(1):1-10.

Andrade TJAS, Araújo BQ, Citó AMGL, Silva J, Saffi J, Richter MF, et al. Antioxidant properties and chemical composition of technical Cashew Nutshell Liquid (tTCNSL). Food Chemistry 2011;126:1044-1048.

Bess F, Favero S, Vieira SL, Torrent J. The effects of functional oils on broiler diets of varying energy levels. The Journal of Applied Poultry Research 2012;21(3):567-578. 
Braz NM, Freitas ER, Trevisan MTS, do Nascimento GAJ, Salles RPR, Cruz $C E B$, et al. Serum biochemical profile, enzymatic activity and lipid peroxidation in organs of laying hens fed diets containing cashew nutshell liquid. Journal of Animal Physiology and Animal Nutrition 2017;102(1):67-74.

Farias NNP, Freitas ER, Xavier RPS, Braz NM, Souza DH, Tavares TCL. Cashew nut meal subjected to prolonged storage for quail feeding. Brazilian Journal of Animal Science 2017;46:576-583.

Hamad FB, Mubofu EB. Potential biological applications of bio-based anacardic acids and their derivatives. International Journal of Molecular Sciences 2015;16:8569-8590.

Hemshekhar M, Santhosh MS, Kemparaju K, Girish KS. Emerging roles of anacardic acid and its derivatives: a pharmacological overview. Basic \& Clinical Pharmacology \& Toxicology 2011;110:122-132.

Himejima M, Kubo I. Antibacterial agents from the cashew Anacardiumoccidentale (Anacardiaceae) nutshell oil. Journal of Agricultural and Food Chemistry 1991;39:418-421.

Jamroz D, Wertelecki T, Houszka M, Kamel C. Influence of diet type on the inclusion of plant origin active substances on morphological and histochemical characteristics of the stomach and jejunum walls in chicken. Journal of Animal Physiology and Animal Nutrition 2006;90:255-268.

Kumar PP, Paramashivappa R, Vithayathil PJ, Subba Rao PV, Rao AS. Process for isolation of cardanol from technical cashew (Anacardiumoccidentale L.) nutshell liquid. Journal of Agricultural and Food Chemistry 2002; 50:4705-4708

Lee KW, Evert H, Kappert HJ, Frehner M, Losa R, Beynen AC. Effects of dietary essential oil components on growth performance, digestive enzymes and lipid metabolism in female broiler chickens. British Poultry Science 2003;44:450-457.

Leite AS, Dantas AF, Oliveira GL, Gomes Júnior AL, de Lima SG, Citó AM, et al. Evaluation of toxic, cytotoxic, mutagenic, and antimutagenic activities of natural and technical cashew nutshell liquids using the Allium cepaand Artemia salina bioassays. BioMed Research International 2015;2015:1-16.

López CAA, Lima KRS, Manno MC, Tavares FB, Fernandes Neto DL, Jesus MLC, et al Effects of cashew nutshell liquid (CNSL) on the performance of broiler chickens. Arquivo Brasileiro de Medicina Veterinária e Zootecnia 2012;64:1027-1035.

Mazzetto SE, Lomonaco D, Mele G. Óleo da castanha-de-caju: oportunidades e desafios no contexto do desenvolvimento e sustentabilidade industrial. Química Nova 2009;32:732-741.

Murakami AE, Eyng C, Torrent J. Effects of functional oils on coccidiosis and apparent metabolizable energy in broiler chickens. Asian-Australasian Journal of Animal Sciences 2014;27:981-989.

Murata M, Irie J, Homma S. Inhibition of lipid synthesis of bacteria, yeast and animal cells by anacardic acids, glycerol3-phosphate dehydrogenase inhibitors from ginkgo. Food Science and Technology 1997;30:458463.

Muzaffar S, Chattoo BB. Apoptosis-inducing (Aif1) mediates anacardic acid-induced apoptosis in Saccharomyces cerevisiae. Apoptosis 2017;22:463-474.

Ojewola GS, Okoye FC, Agbakuru I. Replacement value of cashew-nut meal for soyabean meal in finishing broiler chickens. International Journal of Poultry Science 2004;3(8):513-516.
Paramashivappa P, Kumar PP, Vithayathil PJ, Rao AS. Novel method for isolation of major phenolic components from cashew (Anacardium occidentale L.). Journal of Agricultural and Food Chemistry 2001;49:2548-2551.

Parasa LS, Tumati SR, Kumar, LCA, Chigurupati SP, Rao GS. In vitro antimicrobial activity of cashew (Anacardiumoccidentale, L.) nuts shell liquid against methicillin resistant Staphylococcus aureus (MRSA) clinical isolates. International Journal of Pharmacy and Pharmaceutical Sciences 2011;3(4):436-440.

Rostagno HS, Albino LFT, Donzele JL, Gomes PC, Oliveira RF, Lopes DC, et al. tabelas brasileiras para aves e suínos: composição de alimentos e exigências nutricionais. 3.ed. Viçosa: UFV/DZO; 2011

SAEG - Sistema para Análises Estatísticas. SAEG 9.1. Viçosa: Fundação Arthur Bernardes; 2007

Simsek UG, Ciftci M, Dalkilic B, Guler T, Ertas ON. The effects of dietary antibiotic and anise oil supplementation on body weight, carcass characteristics and organoleptic analysis of meat in broilers. Revue de MedicineVeterinaire 2007;158:514-518.

Stasiuk M, Kozubek A. Biological activity of phenolic lipids. Cellular and Molecular Life Sciences 2010;67:841-860.

Su WC, Lin YF, Yu XP, Wang $Y X$, Lin XD, Su QZ, et al. Mitochondriaassociated apoptosis in human melanoma cells induced by cardanol monoene from cashew nutshell liquid. Journal of Agricultural and Food Chemistry 2017;65:5620-5631.

Tanod WNL, Murwani R, Susanti S, Kusumanti E. Apple powder into diet can increase body weight and intestinal relative weight in broiler. Pakistan Journal of Nutrition 2015;14(9):629-631.

Toyomizu M, Okamoto M, Ishibashi T, Chen Z, Nakatsu, T. Uncoupling effect of anacardic acids from cashew nutshell oil on oxidative phosphorylation of rat liver mitochondria. Life Sciences 2000;66:229234.

Toyomizu M, Nakai Y, Nakatsu T, Akiba Y. Inhibitory effect of dietary anacardic acid supplementation on cecal lesion formation following chicken coccidial infection. Animal Science Journal 2003;74:105-109.

Toyomizu M, Okamoto M, Ishibashi T, Chen Z, Nakatsu T. Uncoupling effect of anacardic acids from cashewnutshell oil on oxidative phosphorylation of rat liver mitochondria. Life Sciences 2000;66:229-234.

Trevisan MTS, Pfundstein B, Haubner R, Würtele G, Spiegelhalder $B$, Bartsch $\mathrm{H}$, et al. Characterization of alkyl phenols in cashew (Anacardiumoccidentale) products and assay of their antioxidant capacity. Food and Chemical Toxicology 2006;44:188-197.

Windisch W, Schedle K, Plitzner C, Kroismayr A. Use of phytogenic products as feed additives for swine and poultry. Journal of Animal Science 2008;86:E140-E148

Zeng Z, Zhang S, Wang H, Piao X. Essential oil and aromatic plants as feed additives in non-ruminant nutrition: a review. Journal of Animal Science and Biotechnology 2015;6(1):7.

Trevisan MTS, Pfundstein B, Haubner R, W€urtele G, Spiegelhalder B, Bartsch $\mathrm{H}$, et al. Characterization of alkyl phenols in cashew (Anacardium occidentale) products and assay of their antioxidant capacity. Food and Chemical Toxicology 2006;44:188-197. 